\title{
AMENDMENTS
}

\section{Author Correction: An unshakable carbon budget for the Himalaya}

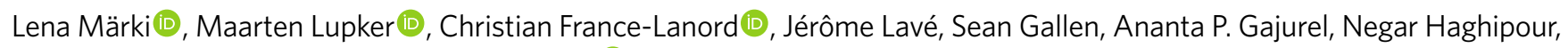
Fanny Leuenberger-West and Timothy Eglinton (10)

Correction to: Nature Geoscience https://doi.org/10.1038/s41561-021-00815-z, published online 20 September 2021.

In the version of this article originally published, there was an error in equation (15). Originally reading " $\mathrm{C}_{\text {released }}=\operatorname{Re}_{\text {flux }} \times\left(\mathrm{OC}_{\mathrm{sd}} / \mathrm{Re}_{\mathrm{sd}}\right) \times$ $f_{\mathrm{C}}-f_{\text {graphite }}$ ", the equation has been amended to read " $\mathrm{C}_{\text {released }}=\mathrm{Re}_{\text {flux }} \times\left(\mathrm{OC}_{\mathrm{sd}} / \mathrm{Re}_{\mathrm{sd}}\right) \times f_{\mathrm{C}} \times\left(1-f_{\text {graphite }}\right)$."

The change has been made to the HTML and PDF versions of the article.

Published online: 10 February 2022

https://doi.org/10.1038/s41561-021-00882-2

(c) The Author(s), under exclusive licence to Springer Nature Limited 2021

\section{Publisher Correction: Machine learning in Earth and environmental science requires education and research policy reforms}

Sean W. Fleming (1), James R. Watson, Ashley Ellenson, Alex J. Cannon (1) and Velimir C. Vesselinov

Correction to: Nature Geoscience https://doi.org/10.1038/s41561-021-00865-3, published online 2 December 2021.

In the version of this article originally published, there were errors in refs. 5-7. Originally listed as Hutchinson (2018), Karpatne (2017), McGovern (2019), the order of refs. 5-7 has been corrected to read McGovern (2019), Hutchinson (2018)), Karpatne (2017), respectively.

The change has been made to the online version of the article.

Published online: 24 December 2021

https://doi.org/10.1038/s41561-021-00881-3

This is a U.S. government work and not under copyright protection in the U.S.; foreign copyright protection may apply 2021 